Moments of Silence 



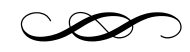

\title{
Moments of Silence
}

\author{
$\infty$ \\ The Unforgetting of the October 6, 1976, \\ Massacre in Bangkok
}

Thongchai Winichakul

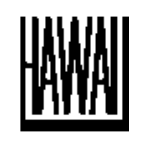

University of Hawai'i Press

Honolulu 


\section{(C) 2020 University of Hawai'i Press \\ All rights reserved \\ Printed in the United States of America \\ $252423222120 \quad 6554321$}

\section{Library of Congress Cataloging-in-Publication Data}

Names: Thongchai Winichakul, author.

Title: Moments of silence : the unforgetting of the October 6, 1976, massacre in Bangkok / Thongchai Winichakul.

Description: Honolulu : University of Hawai'i Press, 2020. I Includes bibliographical references and index.

Identifiers: LCCN 2019050498 I ISBN 9780824882334 (cloth) I ISBN

9780824882341 (paperback) I ISBN 9780824882860 (epub) I ISBN

9780824882877 (kindle edition) I ISBN 9780824882853 (pdf)

Subjects: LCSH: Thammasat University Massacre, Bangkok, Thailand, 1976. I

Collective memory-Thailand. I Psychic trauma-Thailand. I Political activists-Thailand-History-20th century. I Thailand-Politics and government-20th century.

Classification: LCC DS586 .T578 2020 I DDC 959.304/4—dc23

LC record available at https://lccn.loc.gov/2019050498

University of Hawai'i Press books are printed on acid-free paper and meet the guidelines for permanence and durability of the Council on Library Resources.

Cover art and design: Ben Winitchakul. When I Was 8 Years Old. 